\title{
Current Status and Prospect of College Physical Education Reform from the Perspective of Humanity
}

\author{
Yaoliang Zhang \\ Zhuhai College of Jilin University \\ 279399748@qq.com
}

Keywords: Physical education reform; Humane thought; Current status

\begin{abstract}
Nowadays, the living standard of our society has risen obviously. Along with the continuous development and progress of the economy, the educational work of colleges and universities has made rapid progress. At present, the education department of our country has made it clear that in the efficient teaching of physical education, whether it is the mode or way, it should change to the pluralistic direction. This article mainly analyzes the present situation and future development of PE teaching in the view of humanity. Because of sports education in colleges and universities and primary and secondary school education in China has largely changed, makes the education mode and on the way to the corresponding to change, this is because in the process of middle and primary school sports education, exam-oriented education made sports development cannot be all aspects, but in sports education in colleges and universities, environmental conditions and the student psychology is very mature, to the understanding of physical education are fully and reasonable psychological needs, at the same time, college education as a student in the last stage of learning career, should fully display education the characteristic of human nature, also can let students better all-round development. At present, our country emphasizes the humanized education concept, and in the aspect of curriculum teaching methods and goals, and so on are especially pay attention to this point, it also indicates the direction of the education for our country's university sports.
\end{abstract}

\section{Results Obtained in Reform of China's Physical Education Reform}

Nowadays, the concept of humanization has entered the teaching thought; our country has entered the new period of physical education, because people's awareness and demand for exercise is increasing, so that colleges and universities gradually derived from the theme of student-oriented happy education and personalized education. Species concept, which enriched and expanded China's educational philosophy. But also on the dimensions of diversity, a comprehensive study of the physical education in colleges and universities in the form and content, and its processing to more fit the modern students, as well as more humane. This more humane evolution of educational philosophy, but also more able to show that education can stand in the interests of their own students in this market, that is, education is really for the development of students, so that students can get better individualized and comprehensive development.

Physical Education Teaching at Colleges is More Scientific. Nowadays, the curriculum of colleges and universities in our country is being adjusted gradually, and the mode of self-selecting students is being gradually improved. This shows that the individualized teaching reform in China has also yielded some achievements, and gradually evolved three-stage, parallel- The effective combination of three different modes of this education mode, for different schools, to learn the rational choice based on these three models, the premise is to analyze the actual situation of the school, and can establish with their own teaching characteristics of the teaching model. It is precisely because colleges and universities have this important concept of people-centered, will make the classroom organization and teaching methods can continue to reform and innovation. All in all, these user-friendly teaching methods can increase the enthusiasm of the students themselves, based on the overall effectiveness of the classroom teaching to enhance effectively. 
Physical Education Curriculum in Colleges and Universities Is Gradually Enriched. After China promotes the concept of humane teaching, each of China's colleges and universities has slowly set up a different physical education curriculum, and students can make reasonable choice according to actual situation of their own and the school. For this part of curriculum, they are very complicated and diversified in both quantity and category. Most of they cover the more traditional sports categories, such as gymnastics, track and field, volleyball, and badminton, aerobics and so on the project, national projects, including martial arts, free combat and shuttlecock as well as intellectual projects like chess, backgammon and chess, and so on. At present, there are many items that contain more fashion sense, such as tennis, hip-hop, yoga in college physical education.

In such teaching mode with a good combination of various projects, a combination of leisure and economy has been really formed at colleges and universities combing physical agility and intellectual training so as to real achieve the purpose of satisfying students' personalized demands.

\section{Problems in the Current Reform of China's College Physical Education}

Teachers' Quality is Slightly Insufficient. Before the formal teaching mode of human nature, the educational idea and goal of the physical education curriculum in Colleges and universities in our country have been gradually updated and gradually explored. In people-oriented teaching philosophy, and no more display. This makes human education is too simple and inadequate. However, for the majority of physical education teachers, the education before the actual entry is relatively simple, the lack of people-oriented teaching methods and models, such as the specific concept of the specific application of communication. [1] There is also the status quo in the process of teaching in physical education teachers in Colleges and universities in our country, lack of motivation to study the phenomenon. The appearance of this phenomenon will bring a very big influence on the popularization and innovation of the humanized teaching idea in our country. However, in the aspect of physical education teaching, there is still a way to explore and study in the implementation of new ideas and new names. In this way, the teacher as the leader of the whole event, if we cannot have a role in strengthening the concept of people-oriented, it will make the effect of classroom teaching unsatisfactory.

Actual Teaching Still Has Problems. Since the implementation of college sports reform in China, even in the relevant areas, there have been considerable achievements, so that the concept of human education and education model has also been the consensus of teachers and students. But in practice, there is still too much emphasis on the theory and ignore the actual drawbacks, it is this gap between theory and practice, it makes the actual work of college physical education have a certain degree of difficulty in the classroom teaching practice with a more traditional system-style education, that is, the classroom teaching mode and teaching methods have a teacher who decided regardless of the idea of the students. The phenomenon of the emergence of this phenomenon and some college sports teachers but their lack of good sense of the superposition of the service will result in the actual teaching of the role of the teacher too prominent, and weakened the status of the subject of their own phenomenon, which students in the classroom content of learning is very inappropriate.

\section{Prospect of the Future of Humane Reform of College Physical Education}

Development of Concept. In recent years, China has achieved long-term progress and development both in social civilization and in economy. The people of our country, as the most important part of the society at present, will be paid more and more attention. Therefore, in this social background, people-oriented thinking is particularly important, but the reform of college physical education in China, must also closely follow the trend and philosophy, and can be applied to their own teaching work, teaching this kind of humanized teaching mode is the important development trend of college physical education reform in our country. But it is an important guarantee for college students to get comprehensive development. 
Establish Evaluation System. It is very important to have a comprehensive evaluation system for college PE teaching. This is because of the supervision of the curriculum evaluation system, can effectively help students to their own learning attitude and the results have a good understanding, so as to help them effectively correct and innovate. And standing on the perspective of curriculum evaluation, but also can make the teaching work really stand in the student's point of view so that human nature of the teaching philosophy can be fully implemented in every course, the teacher can use multi-field, multi-angle model of classroom education has a comprehensive evaluation. At the same time, as a teacher, but also to fully respect the differences of each student, because each student is independent and different, they have their own human characteristics. Therefore, the teacher should learn to use the comprehensive evaluation system to enable students to obtain better learning results. Establish their learning self-confidence, so that they can effectively active learning, and allow them to have a good learning habits and physical exercise awareness.

Improve Methods. At present, in our country's independent learning platform, we can clearly see that the physical education in our country, whether in the way or in the above methods, are more diverse and rich. The most important thing is to effectively combine the actual characteristics of the school, flexible, can be used in the practical aspects of continuous optimization, continuous innovation. However, with the continuous increase of the physical education curriculum resources in our country, the number of courses offered by the colleges and universities in our country will gradually increase, and the concept and content of human resources will be enhanced. At the same time, the establishment of physical education courses in Colleges and universities should also be in accordance with the actual needs of students, in order to ensure that the curriculum is reasonable and effective. With the optimization of physical education curriculum resources, the school and the school can also form a favorable situation of resource sharing. Because this way can not only provide more excellent learning resources and opportunities for students, can also help the friendly communication and exchange between the school and the school, with the continuous promotion of this people-oriented concept and advocate. [2] It will also make the analysis of the physical education curriculum in our country and the workload of the research and innovation.

Create Teaching Atmosphere. In terms of physical education in China's colleges and universities, in order to make the humanization of the teaching be guaranteed, we must start from the environment, for example, can effectively use the existing resources of the school, and mobilize the venue, equipment and other effective facilities to help improve the learning environment for students. For teachers, it must let students in their introduction and understanding, through the relatively concrete teaching links to form a true sense of humanity teaching. At the same time, teachers in the actual teaching process, and always maintain the interaction with students, and this interaction must be equal, so as to ensure effective communication between teachers and students can ensure that education can really be implemented.

Improve Teachers' Quality. Teachers are the main leaders of education, especially in the process of college physical education. Therefore, teachers must have a good sense of service to ensure that the students as the main object of education in the classroom, the only way to be able to achieve the true sense of education to enhance the teaching work to achieve real results. At the same time, teachers should always strengthen the learning after work, and must not be satisfied with the status quo, we must always innovate their own educational philosophy, always improve their own knowledge system. In addition, teachers also maintain good interaction with students and communication, remember that interaction must be equal. And the teachers can also in the actual teaching of each of the key steps, the actual needs of the students a rough consideration, and on the basis of this demand to carry out the next teaching work and activities. And most importantly, the teacher must have a correct, people-oriented teaching philosophy, the only way to be in the actual education process to understand the students, respect for students, and from all aspects to meet the needs of students and development aspirations. 


\section{Measures to Improve Reform in College Physical Education from Humane Perspective}

Necessity to Humane Reform in College Physical Education. Since China began to rise after the educational reform, in the domestic society has also undergone a great degree of change. People as the most basic elements of society, and social development are inextricably linked. Therefore, people should gradually realize the importance of the concept of people-oriented, especially in the education process. In practice, the college physical education should pay full attention to this idea, and to seriously implement it to the actual operation process, from inquiry mode to application, people will pay more and more attention to humanization reform, humanization Reform is the inevitable trend of social development and progress. These reform methods can not only help students to develop and progress in an all-round way, but also improve the overall psychological quality and have a great effect on the development of quality education.

Improve Teachers' Professional Quality. Teachers, as professionals organizing and the implementing educational activities, should have sufficient reserves of knowledge, high moral character and a more comprehensive sense of service, and the meaning of humanity should have a general understanding and a full understanding of human nature of the teaching methods and models to have full awareness of learning. Only in this way can we strive to increase their degree of professional knowledge and professionalism. In addition, teachers should be people-oriented concept of the implementation of the actual teaching work, but also establish the teaching philosophy of equality between teachers and students. All in all, teachers must adapt to the trend of human development, to ensure that the overall quality of the students to enhance. Schools to combine the school's own development and the actual situation of students in order to meet the needs of students in sports, and strive to be students as the main body of education, students play as the main body of the true meaning of human teaching can really play its education effect.

Establish and Improve the Curriculum Evaluation System. To ensure that the physical education in Colleges and universities can have a complete scientific curriculum evaluation system. In the course of the evaluation of the students to give up watching this exam only in the traditional teaching model, combining the learning process and the results of the students, cannot blindly look at results and ignore the students' learning process. Teachers in the evaluation of the effectiveness of teaching and learning students to their own teaching methods, ideas and the results of the effective combination of teaching students, must not consider only one aspect. [3] In carrying out the assessment, we should carry out the idea of quality education, the idea of human nature education, take full account of the individual differences in the objective existence of students, and strengthen the comprehensive and comprehensive investigation. In addition, the teachers also need to realize the real needs of the students for the teaching work, scientific and reasonable and effective development of students to promote the enthusiasm and creativity of the evaluation method and evaluation system.

Creating a Humane Teaching Environment. To truly realize the purpose of humanization of education, not only need to make full use of educational resources of the school, reasonable arrangements, but also the school on campus to carry out a broad sense of publicity. In addition, the school should strengthen the teacher's ideological education, to help teachers to enhance the understanding of the concept of human teaching. Teachers must recognize that students should be equal communication between the teaching and learning, we must create a regular interaction, often exchange of teaching and equality, harmony, democracy, teacher-student relationship, from the perspective of human development, practical arrangements. Arrange reasonable teaching contents and curriculum, analyze differences of each student and their own situation so as to strive to innovate teaching mode, diversify teaching modes and achieve obvious teaching effects.

\section{Conclusion}

Humane education will absolute become the main trend of China's future education mode, which is of great importance. Therefore, during the teaching process, higher education must be closely 
associated with the actual development of students and the school so as to make more humanistic, scientific and reasonable teaching mode and achieve better teaching effects.

\section{References}

[1] Yang Dong, Xiong Manli, Tan Zhigang, Zou Weiguo. A Review of Researches on the Reform of Public Physical Education in Chinese Universities from 2000 to 2009 [J]. Journal of Jilin Institute of Physical Education, 2010, (3)

[2] Xin Wei. Research on the Positive Motivation of Team Assessment in Physical Education Curriculum Evaluation of Colleges and Universities [J]. Journal of Henan Institute of Education (Natural Science), 2014, (1)

[3] Duan Jianzhi, Liu Haiyuan, Peng Jianmin, Long Songjun. Effective Collocation of Physical Education Curriculum in Universities (II) - Research Based on Curriculum Knowledge [J]. Journal of Physical Education, 2011, (6) 